THE THEORY OF MONEY AND FINANCE 
Related titles from Macmillan Education

R. W. Evans and G. H. Makepeace: MONETARY THEORY, INSTITUTIONS AND PRACTICE

C. A. E. Goodhart: MONEY, INFORMATION AND UNCERTAINTY

Brian Morgan: MONETARISTS AND KEYNESIANS

J. Ribaud: THE MECHANICS OF MONEY 


\title{
THE THEORY OF MONEY AND FINANCE
}

\author{
RICHARD COGHLAN
}




\title{
(C) Richard Coghlan 1980
}

\begin{abstract}
All rights reserved. No part of this publication may be reproduced or transmitted, in any form or by any means, without permission.
\end{abstract}

First published 1980 by

THE MACMILLAN PRESS LTD

London and Basingstoke

Associated companies in Delhi Dublin

Hong Kong Johannesburg Lagos Melbourne

New York Singapore and Tokyo

British Library Cataloguing in Publication Data

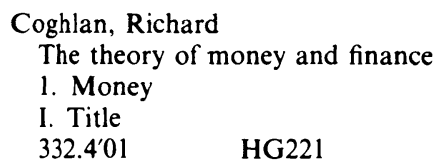

ISBN 978-0-333-25644-2

ISBN 978-1-349-86121-7 (eBook)

DOI 10.1007/978-1-349-86121-7

This book is sold subject to the standard conditions of the Net Book Agreement.

The paperback edition of this book is sold subject to the condition that it shall not, by way of trade or otherwise, be lent, resold, hired out, or otherwise circulated without the publisher's prior consent, in any form of binding or cover other than that in which it is published and without a similar condition including this condition being imposed on the subsequent purchaser. 
To Wynrhys 


\section{CONTENTS}

Preface $\quad$ xi

Acknowledgements xiii

1. THE FUNCTIONS OF MONEY 1

The Development from Barter to a Monetary Economy

The Characteristics of Money

2. MONEY IN MACROECONOMIC MODELS 14 The Quantity Theory of Money 14

Keynes and the IS/LM Model 17

Criticisms of the IS/LM Model 27

Expenditure Financing and Crowding-out 29

Including an External Sector 36

Appendix Diagrammatic Derivation of the IS/LM Model

3. THE CAUSALITY DEBATE 48

Outline of Debate 48

Evidence for the United Kingdom $\quad 57$

Criticisms and Comments $\quad 65$

Conclusion $\quad 71$

Appendix Statistical Evidence of Monetary Causality

4. THE THEORY OF THE DEMAND FOR MONEY 75

Keynes-The General Theory of Employment, Interest and Money

Criticisms

Why the Transactions Demand for Money should be Interest-elastic Optimal Precautionary Cash Balances

75

81

84

89 
Portfolio Analysis of the Demand for Money

Friedman's Reformulation of the Quantity Theory

5. ESTIMATING THE DEMAND FOR MONEY

A General Discussion of the Specification and Data

The Identification Problem

Lags

The Importance of the Definition of Money

Summary of Empirical Results

Appendix 5.1 Demand for Money Studies in the United Kingdom - Summary of Results

Appendix 5.2 Demand for Money Studies in the United Kingdom - References

6. BALANCE-SHEETS AND FLOWS OF FUNDS

Flows of Funds

Portfolio Diversification and the Reduction of Risk

7. THE FUNCTIONS OF FINANCIAL MARKETS

The Demand for and Supply of Finance $\quad 160$

The Importance of Financial Markets

Summary of Financial Relationships

8. FINANCIAL INTERMEDIATION

The Role of Financial Intermediaries

The Effect of Financial Intermediation on the Level of Capital Accumulation

Financial Structure of Financial Intermediaries $\quad 191$

Operation of Financial Intermediaries

9. THE SUPPLY OF MONEY: THE

MULTIPLIER APPROACH

Money Multiplier Models

The New View

Banks versus N.B.F.I.s

Flexibility of the Financial System 
Appendix Derivation of Equations (9.20) and (9.25)

10. THE SUPPLY OF MONEY AND THE DYNAMICS OF ADJUSTMENT

The Money Supply and Credit Demand

The Process of Adjustment

Monetary Disequilibrium and the Balance of

Payments

Defining Foreign Reserves

Sterilisation of External Currency Flows

Controlling the Money Supply

An Interpretation of the 1970s

Conclusion

Notes

References

Author Index 


\section{PREFACE}

This is a practical book, or that at least is its intention. It introduces the concept of money and deals comprehensively with the basic monetary theory required for an undergraduate course on money or macroeconomics. There is also, however, detailed discussion of empirical work in the area of monetary economics, and emphasis is placed on the problems encountered in giving practical expression to abstract theory. In this context it is particularly necessary to distinguish clearly between the various possible definitions of money. While this is likely to prove crucial to the role money is to play in the economy, it is very poorly dealt with in the literature, and more usually money is presented as an homogeneous commodity, implying that it makes no difference to, say, the specification of a demand for money function which definition is employed.

An introduction to flow-of-funds accounting, and the operation, and significance, of financial markets and institutions is also provided. It is hoped that this will help the student to relate his economic theory to the published data and to existing financial institutions. Often, theory is presented in a completely abstract manner and little attempt is made to introduce the student to the raw data which will form a basic material input to any practical application of economics.

The financial institutions, and the financial flows they generate, are generally not dealt with in any detail, and yet they are fundamental to an understanding of the role of money, and are anyway important in their own right. The economy, and the financial markets and institutions, develop together, and any study of the growth of output requires an explanation of how the increasing financing requirements are accommodated.

Finally, the process of money-supply creation is dealt with in some detail. This is in two parts. The first, Chapter 9, deals with the standard money multiplier approach and the criticisms that have been raised against it, in particular the debate surrounding the 'New View'. The second part, Chapter 10, develops an 
argument in terms of the lending activities of banks to explain the process of money creation. This provides a dynamic, disequilibrium, framework which justifies a direct relationship between the supply of money and income/expenditure markets. There have already been some interesting empirical studies which have attempted to explain the importance of money within disequilibrium models, and the number of such studies is increasing.

This book is primarily intended for students following a second- or third-year course in monetary or macroeconomics, and who have already become familiar with elementary economic theory. It should, however, also have a wider use. It should prove useful for courses dealing with financial analysis and portfolio choice, providing a link with the operation of financial institutions and the role of money and finance in the economy. In addition, much of the book should be accessible to those working in a financial market environment.

The practical approach adopted, and the requirements of modern applied economics, have required the occasional inclusion of a few econometric and statistical terms. These need not cause concern to those unfamiliar with the terminology, and it should be possible to follow the presentation without necessarily understanding the detailed derivation.

Much of the material included in this book was originally written up in separate papers, and, at that stage, benefited from discussions with colleagues both inside the Bank of England and elsewhere. In particular I would like to thank Charles Goodhart for his perceptive comments. In addition I am most grateful to Michael Artis and Brian Hilliard, who have read the book in its complete form and whose comments and suggestions have been invaluable. The Bank of England were generous enough to provide facilities for drawing the many diagrams included in the book, and I am indebted to Amy Crosby, and all those involved, for their splendid work. Finally, I would like to thank my family, who have provided support and inspiration during the long evenings and weekends that I have been locked away in my study. 


\section{ACKNOWLEDGEMENTS}

The author and publishers wish to thank the following, who have kindly given permission for the use of copyright material:

Bank of England, for a table from Quarterly Bulletin (June 1970).

Federal Reserve Bank of St Louis, for tables from Review (April 1970).

Gower Press, for a table from Financial Services Review 197273.

Lloyds Bank Ltd, for two charts from Lloyds Bank Review (July 1978).

London Business School, for a table from Economic Outlook 1977-80.

North-Holland Publishing Company, Amsterdam, for a table from Review of Economics and Statistics (November 1966). 